\title{
Application of Time Series Box-Jenkins Method (ARIMA) to Forecast The Highest and Lowest Stock Prices of PT.Semen Indonesia,Tbk.
}

\author{
$1^{\text {st }}$ Hasanatul Iftitah \\ Mathematics Department \\ Universitas Negeri Padang \\ Padang, Indonesia \\ chokeyta@gmail.com
}

\author{
$2^{\text {nd }}$ Dewi Murni \\ Mathematics Department \\ Universitas Negeri Padang \\ Padang, Indonesia \\ dewimunp@gmail.com
}

\begin{abstract}
Stock is one of the investment instruments in demand today. Investors must be smart in making a decision to sell or buy stock in order to avoid losses. For that, investors need the highest and lowest stock price predictions as a basis for consideration in making decisions. PT. Semen Indonesia, Tbk is one of the state-owned companies with defensive stock and included in the LQ45 Index where the liquidity level of stock trading is high so it becomes one of the investors' choices. This study aims to see how ARIMA method forecast stock prices PT. Semen Indonesia, Tbk and how the results of stock price prediction for the next 30 periods. ARIMA method is one of forecasting technique applied for analysis and forecasting time series data and ARIMA is combination between models AR, MA and differencing until stationary data. The result of this research is model ARIMA $(3,1,3)$ to predict the highest stock price of PT. Semen Indonesia,Tbk and the highest stock predictions ranged from $R p .6,862$ to $R p$. 7,040. Also, model ARIMA $(3,1,5)$ to predict the lowest stock price PT. Semen Indonesia,Tbk and the lowest stock predictions ranged from Rp. 6,313 to Rp. 6.508 .
\end{abstract}

Keywords- Stock Prices, ARIMA Method, PT.Semen Indonesia,Tbk.

\section{INTRODUCTION}

Stock are securities that show the ownership portion of an investor or party (business entity) to the related company. Meanwhile, the stock price is the price that arises as a result of the movement of demand and supply that appears in the securities market to the stocks concerned. Stock market prices are the most frequently used for capital market research because stock market prices are most important to investors. Stock market prices are a reference for investors and company management to make decisions.

In stock trading transactions in the capital market, an investor and investment manager (MI) is faced with the decision to want to sell or want to buy stocks. The problem is, if investors are not smart in making decisions, it will cause losses to the investors themselves. Usually, investors buy stocks when the stock price is low and sell when the stock price is high. For this reason, investors need information about the prediction of the highest stock price and the lowest stock price as one of the considerations in making a decision.
One of the new indicators to predict stock prices that are widely used now is the Autoregressive Integrated Moving Average (ARIMA). Where, the ARIMA method is a time series model forecasting technique developed by George Box and Gwilyn Jenkins (1976) which is applied for the analysis and forecasting of time series data, time series analysis is used to analyze data that considers the influence of time. ARIMA (Autoregressive Integrated Moving Average) is a combination of autoregressive models, moving averages and differentiation. ARIMA is a type of linear model capable of representing non-stationary and stationary time series data [6].

The Autoregressive Model (AR) was first introduced by Yue (1926) and developed by Walker (1931), while the Moving Average (MA) model was first used by Slutzky (1937) but it was Wold (1938) which produced the theoretical underpinnings of the combination process ARMA. Worl formed the ARIMA model which was developed in three stages, namely, efficient identification and assessment procedures (for ARIMA and ARIMA mixed processes) [4].

The Autoregressive model (AR) states the dependence of the observed value of a time series with the previous time series. The Autoregressive (AR) model in $p$ is denoted by AR (p). In general for the P-order AR process as follows:

$\operatorname{ARIMA}(\mathrm{p}, 0,0)$ or $\operatorname{AR}(\mathrm{p})$

$X_{t}=\mu^{s}+\varphi_{1} X_{t-1}+\varphi_{2} X_{t-2}+\cdots+\varphi_{p} X_{t-p}+e_{t}(1)$

The Moving Average model (MA) states that there is a dependency relationship between successive error values. The moving average $\mathrm{q}$-model is denoted by $\operatorname{MA}(\mathrm{q})$. The general form of the MA(q) process is

$\operatorname{ARIMA}(0,0, q)$ or $\operatorname{MA}(\mathrm{q})$

$X_{\mathrm{t}}=\mu^{t}+e_{\mathrm{t}}-\theta_{1} e_{\mathrm{t}-1}-\theta_{2} e_{\mathrm{t}-2}-\cdots-\theta_{p} e_{\mathrm{t}-\mathrm{q}}$

The ARMA model is a mixed model between the Autoregressive (AR) and moving average (MA) models. The general form of the ARMA (p,q) model is:

$$
\begin{aligned}
& \operatorname{ARMA}(\mathrm{p}, \mathrm{q}) \\
& X_{\mathrm{t}}=\mu^{\prime}+\varphi_{1} X_{\mathrm{t}-1}+\varphi_{2} X_{\mathrm{t}-2}+\cdots+\varphi_{\mathrm{p}} X_{\mathrm{t}-\mathrm{p}}+e_{\mathrm{t}}- \\
& \theta_{1} \theta_{\mathrm{t}-1}-\theta_{2} e_{\mathrm{t}-2}-\cdots-\theta_{\mathrm{p}} e_{\mathrm{t}-\mathrm{q}}
\end{aligned}
$$

If non-stationarity is added to the ARMA process mixture, it will become the general $\operatorname{ARIMA}(\mathrm{p}, \mathrm{d}, \mathrm{q})$ model. In 
backshift notation, transformation with differencing operators can be written as: $W_{t}=(1-B)^{d} X_{t}$. $W_{t}$ is the result of differentiation data $X_{t}$ as many as d times and $(1-B)^{d}$ is the difference operator. ARMA modification results by entering the operator above differentiation produce a model ARIMA (p,d,q):

$\left(1-\sum_{p=1}^{p} \emptyset_{p} B^{p}\right)(1-B)^{d} X_{t}=\mu+\left(1-\sum_{q=1}^{q} \theta_{q} B^{p}\right) e_{t}(4)$

PT. Semen Indonesia, Tbk is one of the state-owned companies (BUMN), where stocks of state-owned companies tend to be defensive stocks [2] (tend to be more stable) because they are more secure because they belong to the state. Other than that, PT.Semen Indonesia,Tbk. included in the index calculation LQ45. The stocks of stateowned construction companies (BUMN) have become one of the choices of investors, this is supported by the high level of stock trading liquidity in the capital market and government projects, especially the government which focuses on infrastructure such as Indonesia so that it supports the performance of BUMN construction company stocks [5].

This study aims to see how the ARIMA method is used to predict the highest and lowest stock prices of PT. Semen Indonesia, Tbk and see how the results of forecasting the highest and lowest stock prices of PT.Semen Indonesia,Tbk for the next 30 periods.

\section{RESEARCH METHODS}

A. Types and Data Sources.

This study uses secondary data derived from [3]. The data is in the form of the highest daily stock price and the lowest daily stock price of PT. Semen Indonesia, Tbk., from 1 January 2017 to 3 July 2018 which can be seen in Appendix 1[3]. The data is issued by Bursa Efek Indonesia (BEI) and stock historical data can be downloaded on the website [1] www.finance.yahoo.com.

B. Data analysis technique.

In this study, the analysis used is the Box-Jenkins periodic series method (ARIMA) using statistical software, MINITAB 16. The stages of application of the Box-Jenkins method (ARIMA) are as follows:

1. Data Stationary Check.

2. Temporary ARIMA Model Identification.

3. Parameter Estimation of the ARIMA Model Temporarily.

4. Model Equation Determination (Diagnostic Stage).

5. Selection of the Best ARIMA Model. (Overfitting)

6. Forecasting.

\section{RESULTS AND DISCUSSION}

The data used in this study are the highest and lowest stock price data of PT.Semen Indonesia,Tbk January 1, 2017 until July 3, 2018, totaling 382 data [3]. The time series data will be predicted using ARIMA forecasting method.

\section{A. Stationary Test}

To forecast using the ARIMA method, the data must be stationary first. The first step that must be done is to test the stability of the stock price data. The following will be analyzed whether the data has been stationary or not.

\section{Highest Stock Price}

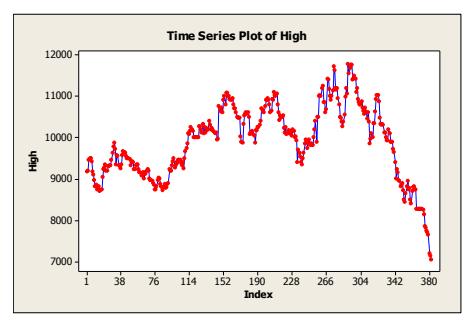

Fig. 1. The Highest Stock Price Plot of PT.Semen Indonesia, Tbk against Time.

By using the graph method, it will be seen whether the data has been stationary or not. It can be seen from Figure 1, the highest stock price data that has been plotted shows a trend pattern or not yet stationary. From Figure 2 it is seen that the ACF coefficient is significantly different from zero and decreases slowly while the PACF approaches zero rapidly after lag-1. This shows that the data is not stationary on average. For this reason, it is necessary to differentiate the data.

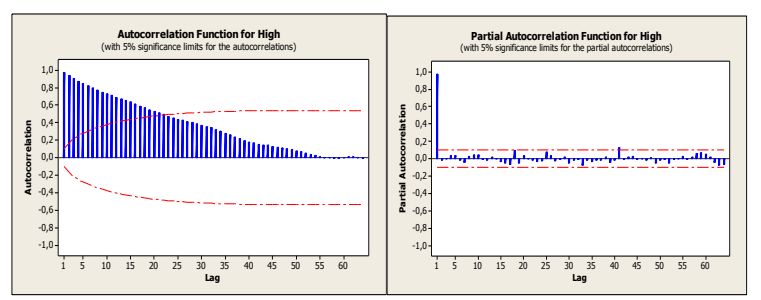

Fig. 2. ACF and PACF Plots Highest Stock Prices of PT.Semen Indonesia, Tbk.

Figure 3 shows the data has experienced the first differencing process. It can be seen that the first data differencing plot against time is quite constant in the middle. So that the data can be said to be stationary in average. And also, judging from the autocorrelation coefficient (Figure 7) data after differencing, if all lags are not significantly different from zero or there are several lags that are different from zero, meaning the data is stationary. The autocorrelation coefficient is not significantly different from zero if the value is within the limit of the evidence interval, that is $0 \pm 0.1004$ where $n$ is the amount of data after differencing. From this differencing process, the parameter value is obtained $\mathrm{d}=1$. 


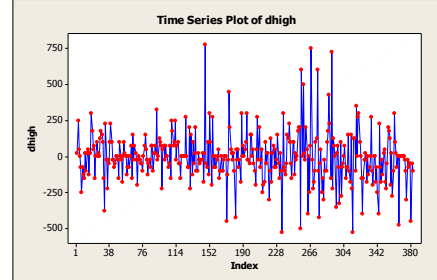

Fig. 3. PT.Semen Indonesia, Tbk's Highest Stock Price Plot, Differencing Level 1.

\section{Lowest Stock Price}

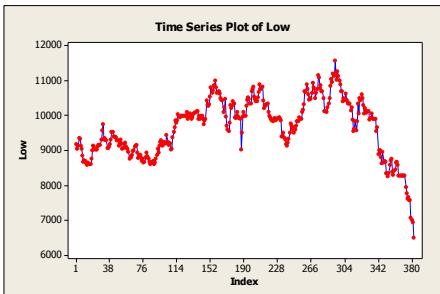

Fig. 4. The Lowest Stock Price Plot of PT.Semen Indonesia Tbk against Time.

By using the graph method, it will be seen whether the data has been stationary or not. It can be seen from Figure 4, the lowest stock price data that has been plotted shows the occurrence of a trend pattern or changes over time, this indicates that the data is not stationary. From Figure 5, it is seen that the ACF coefficient is significantly different from zero and decreases slowly while PACF approaches zero rapidly after lag-1. This shows that the data is not stationary on average. For this reason, it is necessary to differentiate the data.

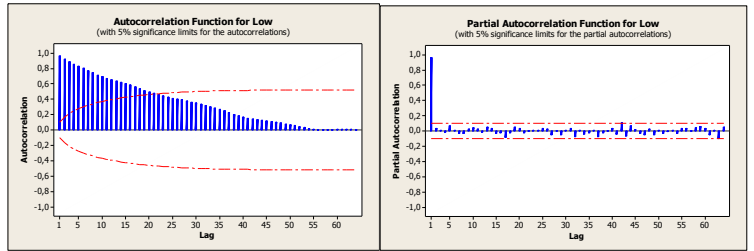

Fig. 5. ACF and PACF Plots Lowest Stock Prices of PT.Semen Indonesia,Tbk.

Figure 6 shows the lowest stock price data has experienced the first differencing process. It can be seen that the first data differencing plot against time is quite constant in the middle. So that the data can be said to be stationary in average. And also, judging by the autocorrelation coefficient (Figure 8) data after differencing, if all lags are not significantly different from zero or there are some lags that are different from zero, it means the data is stationary. The autocorrelation coefficient is said to be no different from zero if the value is within the limit of the evidence interval, that is $0 \pm 0.1004$ where $n$ is the amount of data after differencing. From this differencing process, the parameter value is obtained $\mathrm{d}=1$.

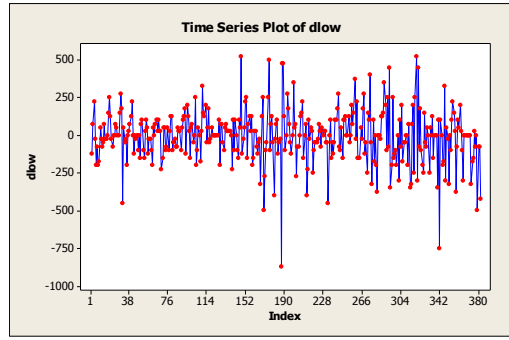

Fig. 6. PT.Semen Indonesia, Tbk's Lowest Stock Price Plot, Differencing Level 1.

\section{B. Identification of the ARIMA Model}

The next step is to identify the ARIMA model that will be used, whether the autoregressive model, the moving average model or the ARIMA model, and determine the temporary model parameter values.

\section{Highest Stock Price}

Based on the ACF and PACF plots (Figure 7) that have been stationary on the first differencing, the ARIMA model that can be used is ARIMA(p,d,q). Judging from the ACF plot shows that there are 3 lags that pass through the limit of the evidence interval $0 \pm 0.1004$ namely lag-16, lag-32 and lag-42 with each value 0.108631, 0.146478 and -0.146370 and 3 lags on the PACF plot, namely lag-32, lag-40 and lag-51 with each value $0.117164,-0.122840$ and 0.108599 , so the parameter limit for $\mathrm{AR}(\mathrm{p})$ is 3 and for the limit of the $\mathrm{MA}(\mathrm{q})$ parameter is 3 . Then the temporary model is chosen $\operatorname{ARIMA}(3,1,4), \operatorname{ARIMA}(3,1,3)$, $\operatorname{ARIMA}(2,1,4), \operatorname{ARIMA}(2,1,3)$.

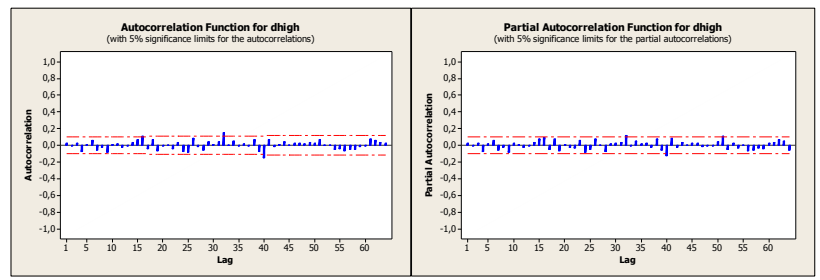

Fig. 7. Plot ACF and PACF of PT.Semen Indonesia, Tbk's Highest Stock Price, Differencing Level 1.

\section{Lowest Stock Price}

Based on the ACF and PACF plots (Figure 8) that have been stationary on the first differencing, the ARIMA model that can be used is ARIMA(p,d,q). Judging from the ACF plot shows that there are 4 lags that pass through the limit of the evidence interval $0 \pm 0.1004$ namely lag-16, lag-31, lag-42 and lag-63 with each value $0.137192,0.130338,0.127628$ and 0.103802 and 4 lags on the PACF plot, ie lag-12, lag-16, lag-31 and lag- 42 with each value of -0.101539 , $0.137627,0.111669$ and 0.102115 , so the parameter limit for $\mathrm{AR}(\mathrm{p})$ is 4 and for the limit of the $\operatorname{MA}(q)$ parameter is 4 . Then the temporary model is chosen, namely $\operatorname{ARIMA}(4,1,5)$, $\operatorname{ARIMA}(4,1,4), \operatorname{ARIMA}(3,1,5), \operatorname{ARIMA}(3,1,4)$. 


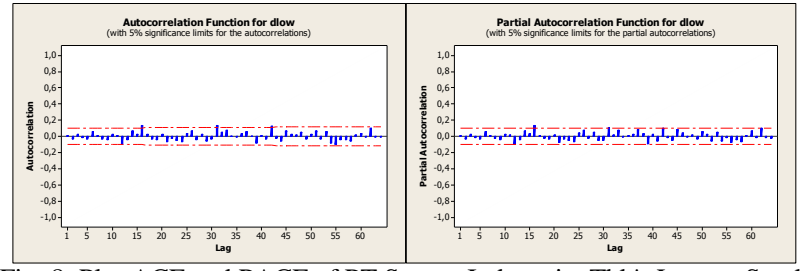

Fig. 8. Plot ACF and PACF of PT.Semen Indonesia, Tbk's Lowest Stock Price, Differencing Level 1.

\section{ARIMA Model Estimation}

The next stage is the parameter estimation stage, where it will be analyzed whether the ARIMA model parameters are significant or not.

\section{Highest Stock Price}

The following is the final estimated value of the model $\operatorname{ARIMA}(3,1,4), \quad \operatorname{ARIMA}(3,1,3)$, $\operatorname{ARIMA}(2,1,3)$ from the output of Minitab 16, while the model $\operatorname{ARIMA}(2,1,4)$ cannot be estimated:

$\operatorname{ARIMA}(3,1,4)$

$\begin{array}{ccccc}\text { Type } & \text { Coef } & \text { SE Coef } & \text { T } & \text { P } \\ \text { AR 3 } & 0,3539 & 0,4957 & 0,71 & 0,476 \\ \text { MA 4 } & 0,0987 & 0,0542 & 1,82 & 0,070 \\ \text { Constant } & -3,283 & 4,985 & -0,66 & 0,511\end{array}$

\section{$\operatorname{ARIMA}(3,1,3)$}

$$
\begin{array}{rrccc}
\text { Type } & \text { Coef } & \text { SE Coef } & \text { T } & \text { P } \\
\text { AR 3 } & 0,3207 & 0,0496 & 6,46 & 0,000 \\
\text { MA 3 } & 0,2876 & 0,0077 & 37,56 & 0,000 \\
\text { Constant } & -13,30 & 21,62 & -0,62 & 0,539
\end{array}
$$

$\operatorname{ARIMA}(2,1,3)$

$$
\begin{array}{crccc}
\text { Type } & \text { Coef } & \text { SE Coef } & \text { T } & \text { P } \\
\text { AR } 2-0,9118 & 0,0797 & -11,45 & 0,000 \\
\text { MA } 3 & 0,0129 & 0,0553 & 0,23 & 0,816 \\
\text { Constant }-0,824 & 1,264 & -0,65 & 0,515
\end{array}
$$

Based on the latest estimates issued by Minitab 16 above, it can be seen that those who meet the requirements for significant parameter estimation are models $\operatorname{ARIMA}(3,1,3)$ where the Pvalue $\mathrm{AR}(3)$ and $\mathrm{MA}(3)$ are $0,000<0,05$.

\section{Lowest Stock Price}

The following is the final estimated value of the model $\operatorname{ARIMA}(4,1,4), \operatorname{ARIMA}(3,1,5)$, $\operatorname{ARIMA}(3,1,4)$ from the Minitab 16 output, while the model ARIMA $(4,1,5)$ cannot be estimated:

\section{$\operatorname{ARIMA}(4,1,4)$}

$$
\begin{array}{rcccc}
\text { Type Coef } & \text { SE Coef } & \text { T } & \text { P } \\
\text { AR 4 }-0,6691 & 0,0979 & -6,83 & 0,000 \\
\text { MA 4 }-0,6362 & 0,0967 & -6,58 & 0,000 \\
\text { Constant }-24,92 & 31,86 & -0,78 & 0,435
\end{array}
$$

$\operatorname{ARIMA}(3,1,5)$

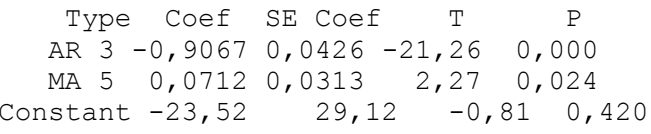

$\operatorname{ARIMA}(3,1,4)$

$$
\begin{array}{crccc}
\text { Type } & \text { Coef } & \text { SE Coef } & \text { T } & \text { P } \\
\text { AR 3 } & 0,1643 & 0,8452 & 0,19 & 0,846 \\
\text { MA 4 } & 0,0687 & 0,0706 & 0,97 & 0,331 \\
\text { Constant } & -10,22 & 12,85 & -0,80 & 0,427
\end{array}
$$

Based on the latest estimates issued by Minitab 16 above, it can be seen that those who meet the requirements for significant parameter estimation are models ARIMA $(4,1,4)$ where the Pvalue $\mathrm{AR}(4)$ and $\mathrm{MA}(4)$ are $0,000<0,05$. Model $\operatorname{ARIMA}(3,1,5)$ also fulfills significant parameter requirements with $\mathrm{P}$-value $\mathrm{AR}(3) 0,000<0,05$ and $\operatorname{MA}(5) 0,024<0,05$.

\section{Diagnosis Test of ARIMA Model}

In this diagnostic test stage, the ARIMA model that has fulfilled the requirements of significant parameter estimation will be tested whether the model is suitable and meets the requirements of white noise means that the residual between the forecasting model and the actual data is small.

\section{Highest Stock Price}

$\operatorname{ARIMA}(3,1,3)$

$$
\begin{array}{ccccc}
\text { Lag } & 12 & 24 & 36 & 48 \\
\text { Chi-Square } & 5,5 & 20,1 & 37,3 & 52,6 \\
\text { DF } & 4 & 16 & 28 & 40 \\
\text { P-Value } & 0,244 & 0,217 & 0,111 & 0,088
\end{array}
$$

It can be seen from the statistical value issued by Minitab 16 above shows the model $\operatorname{ARIMA}(3,1,3)$ meet the requirements of white noise where $\mathrm{P}$-value $>0,05$.

\section{Lowest Stock Price}

$\operatorname{ARIMA}(4,1,4)$

$$
\begin{array}{ccccc}
\text { Lag } & 12 & 24 & 36 & 48 \\
\text { Chi-Square } & 2,8 & 18,2 & 34,0 & 50,4 \\
\text { DF } & 3 & 15 & 27 & 39 \\
\text { P-Value } & 0,426 & 0,250 & 0,165 & 0,105
\end{array}
$$

$\operatorname{ARIMA}(3,1,5)$

$$
\begin{array}{ccccc}
\text { Lag } & 12 & 24 & 36 & 48 \\
\text { Chi-Square } & 4,7 & 18,9 & 34,6 & 50,0 \\
\text { DF } & 3 & 15 & 27 & 39 \\
\text { P-Value } & 0,194 & 0,219 & 0,148 & 0,112
\end{array}
$$

It can be seen from the statistical value issued by Minitab 16 above shows the model $\operatorname{ARIMA}(4,1,4)$ and $\operatorname{ARIMA}(3,1,5)$ meet the requirements of white noise where $\mathrm{P}$-value $>0,05$. 


\section{E. Selection of the Best ARIMA Model}

The next stage is overfitting or choosing the best ARIMA model using criteria MSE (Mean Square Error).

\section{Highest Stock Price}

TABle I. MSE VAlue of the ARIMA Model of THE HigheST STOCK PRICE PT.SEMEN INDONESIA,TBK.

\begin{tabular}{|l|l|}
\hline \multicolumn{1}{|c|}{ ARIMA Model } & \multicolumn{1}{c|}{ MSE value } \\
\hline ARIMA(3,1,4) & 29812 \\
\hline ARIMA(3,1,3) & 28998 \\
\hline ARIMA(2,1,3) & 29615 \\
\hline Output: Minitab 16
\end{tabular}

Can be seen from Table 1 above the smallest MSE value that is the $\operatorname{ARIMA}(3,1,3)$ model with a value of 28998 . From the analysis that has been carried out previously, the author obtained the best model to predict the highest stock price of PT. Semen Indonesia, Tbk namely $\operatorname{ARIMA}(3,1,3)$ which meets the parameters of parameter significance, white noise requirements and has the smallest MSE value. With the equation of the $\operatorname{ARIMA}(3,1,3)$ model as follows, where the AR and MA coefficients can be seen in Appendix 3[3]: $Y_{\mathrm{t}}=-0,2289 Y_{\mathrm{t}-1}+0,7494 Y_{\mathrm{t}-2}+$ $0,8002 Y_{t-a}-0,3207 Y_{t-4}-13,30+$ $1,2845 e_{t-1}+0,5262 e_{t-2}-0,2876 e_{t-9}+e_{t}$

\section{Lowest Stock Price}

TABLE II. MSE VAlue OF THE ARIMA Model OF THE LOWEST STOCK PRICE PT.SEMEN INDONESIA,TBK.

\begin{tabular}{|l|c|}
\hline ARIMA Model & MSE value \\
\hline ARIMA $(4,1,4)$ & 30140 \\
\hline ARIMA $(3,1,5)$ & 29977 \\
\hline ARIMA(3,1,4) & 30296 \\
\hline Output: Minitab 16
\end{tabular}

Can be seen from Table 2 above the smallest MSE value that is the $\operatorname{ARIMA}(3,1,5)$ model with a value of 29977. From the analysis that has been done by the previous author obtained the best model to predict the lowest stock price of PT.Semen Indonesia, Tbk namely ARIMA $(3,1,5)$ which meets the parameters of parameter significance, white noise requirements and has the smallest MSE value. With the equation of the $\operatorname{ARIMA}(3,1,5)$ model as follows, where the AR and MA coefficients can be seen in Appendix 8[3]: $Y_{\mathrm{t}}=0,2436 Y_{\mathrm{t}-1}+0,0404 Y_{\mathrm{t}-2}-0,1882 Y_{\mathrm{t}-\mathrm{a}}+$ $0,9067 \mathrm{Y}_{\mathrm{t}-4}-23,52+0,7770 e_{\mathrm{t}-1}+$ $0,7180 e_{t-2}+0,9185 e_{t-a}-0,0179 e_{t-4}-$ $0,0712 e_{t-5}+e_{t}$

(6)
Indonesia, Tbk using the ARIMA method is forecasting. Where the highest and lowest stock prices for the next 30 periods will be predicted using the best models previously obtained.

\section{Highest Stock Price}

The results of forecasting the highest stock price of PT. Semen Indonesia, Tbk for the next 30 periods using the ARIMA $(3,1,3)$ model issued by Minitab 16 will be shown in Table 3.

It can be seen from Figure 9 that there are some of the highest actual stock prices that are far different from the predicted results. This is caused by stock price movements that are uncertain because there are many factors outside and within the company that affects stock movements. Sometimes the changes that occur are extreme, soaring up or down. This is what causes stocks to be called high-risk investments. In addition, ARIMA forecasting assumes a sustainable pattern, so that the predicted results are in the pattern of a downward trend.

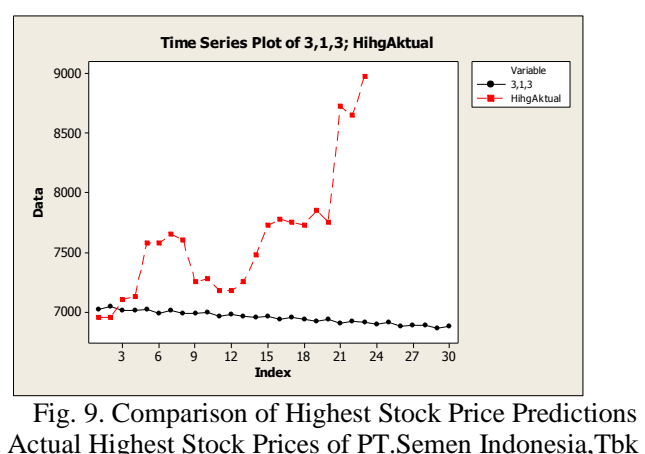

\section{Lowest Stock Price}

The results of the lowest stock price forecasting of PT. Semen Indonesia, Tbk for the next 30 periods using the $\operatorname{ARIMA}(3,1,5)$ model issued by Minitab 16 will be shown in Table 4 .

It can be seen from Figure 10 that there are some actual lowest stock prices that are far different from the predicted results. This is caused by stock price movements that are uncertain because there are many factors outside and within the company that affects stock movements. Sometimes the changes that occur are extreme, soaring up or down. This is what causes stocks to be called high-risk investments. In addition, forecasting ARIMA assumes a continuous data pattern, so that the predicted results are in the pattern of a downward trend.

\section{F. Forecasting}

The final step of the stage of predicting the highest and lowest stock prices of PT. Semen 


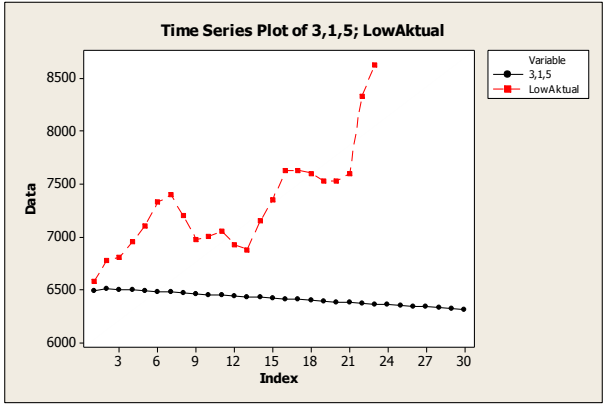

Fig. 10. Comparison of Predictions of Lowest Stock Prices and Lowest Actual Stock Prices of PT.Semen Indonesia,Tbk

Table III. Predictions of the Highest Stock Price of PT.SEMEN INDONESIA,TBK.

\begin{tabular}{|r|c|c|c|c|c|c|c|}
\hline NO & Periode & Tanggal & Prediksi & NO & Periode & Tanggal & Prediksi \\
\hline 1 & 383 & $04 / 07 / 2018$ & 7017,62 & 16 & 398 & $24 / 07 / 2018$ & 6932,07 \\
\hline 2 & 384 & $05 / 07 / 2018$ & 7040,21 & 17 & 399 & $25 / 07 / 2018$ & 6949,48 \\
\hline 3 & 385 & $06 / 07 / 2018$ & 7009,01 & 18 & 400 & $26 / 07 / 2018$ & 6934,64 \\
\hline 4 & 386 & $09 / 07 / 2018$ & 7012,84 & 19 & 401 & $27 / 07 / 2018$ & 6920,83 \\
\hline 5 & 387 & $10 / 07 / 2018$ & 7017,04 & 20 & 402 & $30 / 07 / 2018$ & 6937,2 \\
\hline 6 & 388 & $11 / 07 / 2018$ & 6986,74 & 21 & 403 & $31 / 07 / 2018$ & 6905,65 \\
\hline 7 & 389 & $12 / 07 / 2018$ & 7009,9 & 22 & 404 & $01 / 08 / 2018$ & 6918,85 \\
\hline 8 & 390 & $11 / 07 / 2018$ & 6984,01 & 23 & 405 & $02 / 08 / 2018$ & 6909,71 \\
\hline 9 & 391 & $13 / 07 / 2018$ & 6981,7 & 24 & 406 & $03 / 08 / 2018$ & 6891,2 \\
\hline 10 & 392 & $16 / 07 / 2018$ & 6991,08 & 25 & 407 & $06 / 08 / 2018$ & 6909,26 \\
\hline 11 & 393 & $17 / 07 / 2018$ & 6959,06 & 26 & 408 & $07 / 08 / 2018$ & 6879,71 \\
\hline 12 & 394 & $18 / 07 / 2018$ & 6979,87 & 27 & 409 & $08 / 08 / 2018$ & 6888,13 \\
\hline 13 & 395 & $19 / 07 / 2018$ & 6959,36 & 28 & 410 & $09 / 08 / 2018$ & 6884,45 \\
\hline 14 & 396 & $20 / 07 / 2018$ & 6951,03 & 29 & 411 & $10 / 08 / 2018$ & 6862,16 \\
\hline 15 & 397 & $23 / 07 / 2018$ & 6964,48 & 30 & 412 & $13 / 08 / 2018$ & 6880,72 \\
\hline
\end{tabular}

Table 4. Predictions of the Lowest Stock Prices of PT.Semen Indonesia,Tbk.

\begin{tabular}{|r|c|c|c|c|c|c|c|}
\hline NO & Periode & Tanggal & Prediksi & NO & Periode & Tanggal & Prediksi \\
\hline 1 & 383 & $04 / 07 / 2018$ & 6484,57 & 16 & 398 & $24 / 07 / 2018$ & 6411,1 \\
\hline 2 & 384 & $05 / 07 / 2018$ & 6508,18 & 17 & 399 & $25 / 07 / 2018$ & 6404,75 \\
\hline 3 & 385 & $06 / 07 / 2018$ & 6502,65 & 18 & 400 & $26 / 07 / 2018$ & 6396,82 \\
\hline 4 & 386 & $09 / 07 / 2018$ & 6494,23 & 19 & 401 & $27 / 07 / 2018$ & 6390,81 \\
\hline 5 & 387 & $10 / 07 / 2018$ & 6488,08 & 20 & 402 & $30 / 07 / 2018$ & 6383,29 \\
\hline 6 & 388 & $11 / 07 / 2018$ & 6480,27 & 21 & 403 & $31 / 07 / 2018$ & 6376,96 \\
\hline 7 & 389 & $12 / 07 / 2018$ & 6474,71 & 22 & 404 & $01 / 08 / 2018$ & 6369,08 \\
\hline 8 & 390 & $11 / 07 / 2018$ & 6466,58 & 23 & 405 & $02 / 08 / 2018$ & 6362,88 \\
\hline 9 & 391 & $13 / 07 / 2018$ & 6460,29 & 24 & 406 & $03 / 08 / 2018$ & 6355,45 \\
\hline 10 & 392 & $16 / 07 / 2018$ & 6452,41 & 25 & 407 & $06 / 08 / 2018$ & 6349,15 \\
\hline 11 & 393 & $17 / 07 / 2018$ & 6446,74 & 26 & 408 & $07 / 08 / 2018$ & 6341,35 \\
\hline 12 & 394 & $18 / 07 / 2018$ & 6438,87 & 27 & 409 & $08 / 08 / 2018$ & 6334,99 \\
\hline 13 & 395 & $19 / 07 / 2018$ & 6432,52 & 28 & 410 & $09 / 08 / 2018$ & 6327,59 \\
\hline 14 & 396 & $20 / 07 / 2018$ & 6424,59 & 29 & 411 & $10 / 08 / 2018$ & 6321,31 \\
\hline 15 & 397 & $23 / 07 / 2018$ & 6418,76 & 30 & 412 & $13 / 08 / 2018$ & 6313,62 \\
\hline
\end{tabular}

\section{CONCLUSION}

1. The ARIMA model obtained for the highest stock price of PT.Semen Indonesia,Tbk is model $\operatorname{ARIMA}(3,1,3)$ with the following equation:

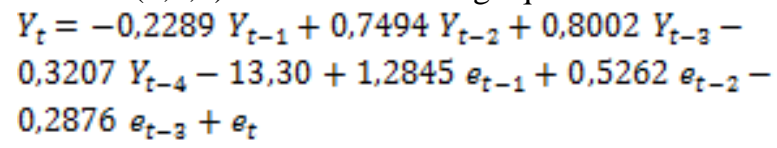

(7)

While the ARIMA model is obtained for the lowest stock price of PT.Semen Indonesia,Tbk is model $\operatorname{ARIMA}(3,1,5)$ with the following equation:

$$
\begin{aligned}
& Y_{\mathrm{t}}=0,2436 Y_{\mathrm{t}-1}+0,0404 Y_{\mathrm{t}-2}-0,1882 Y_{\mathrm{t}-\mathrm{a}}+ \\
& 0,9067 Y_{\mathrm{t}-4}-23,52+0,7770 e_{\mathrm{t}-1}+0,7180 e_{\mathrm{t}-2}+ \\
& 0,9185 e_{\mathrm{t}-\mathrm{a}}-0,0179 e_{\mathrm{t}-4}-0,0712 e_{\mathrm{t}-5}+e_{\mathrm{t}}
\end{aligned}
$$

The highest predicted stock price of PT.Semen Indonesia,Tbk for the next 30 periods ranging from Rp. 6.862 to Rp. 7.040. While the lowest stock prediction results of PT.Semen Indonesia,Tbk range between Rp. 6.313 to Rp. 6.508 .

\section{REFERENCES}

[1] Bursa Efek Indonesia (BEI), "Historis Harga Saham SMGR". www.finance.yahoo.com, Accessed 14 Juli 2018, 2018.

[2] Fahmi. Irham, Pengantar Teori Portofolio dan Analisis Investasi, Bandung: Alfabeta, 2015.

[3] H. Iftitah, "Aplikasi Metode Deret Berkala Box-Jenkins (ARIMA) untuk Meramalkan Harga Saham Tertinggi dan Terendah PT.Semen Indonesia,Tbk". Hasil Penelitian, UNP, 2018.

[4] Makridakis, Spyros,; Wheelwright, Steven C, 1999. Metode dan Aplikasi Peramalan Jilid 1, Edisi Kedua, Jakarta: Binarupa Aksara.

[5] Melani. Agustina, "Saham BUMN Jadi Pilihan Investor", www.liputan6.com/bisnis/read/2436080/saham-bumn-jadi-pilihaninvestor, accessed 20 Juni 2017, 2016.

[6] Putra. Atus Amadi, Perangkat Pembelajaran Mata Kuliah Metode Peramalan, Padang: Bahan Ajar, FMIPA, Universita Negeri Padang, 2012. 